\title{
Indigenous Aquatic Resource Use in Two Tropical Australian River Catchments: the Fitzroy River (W.A.) and Daly River (N.T.).
}

Sue Jackson $^{1}$, Marcus Finn ${ }^{2}$ and Pippa Featherston ${ }^{3}$

11 October 2013

\section{ABSTRACT}

Indigenous people in north Australia extensively utilise wild resources as a food source, for art, craft and medicinal supplies, and these resources are part of a socially and culturally significant landscape. Using data collected during household surveys across two catchments in north Australia, the Daly River (NT) and the Fitzroy River (WA), we describe indigenous aquatic resource use patterns. The Daly River is a perennial system with extensive vegetated wetlands that can remain inundated for long periods of time (4-5 months). In contrast, the Fitzroy River can cease to flow during the winter dry season (May - October) and its floods have residence times that are usually weeks long. Subsistence strategies in the study catchments depend on seasonal availability of a wide array of aquatic species and are attuned to the life histories and movement patterns of key species, such as Long-necked Turtle (Chelodina rugosa) and Magpie Goose (Anseranas semipalmata). Indigenous households in the two study catchments harvested resources from different habitats. The results show a clear progression from use of the main river channel shortly after the wet season to use of billabongs late in the dry season in the Daly River, with a constant reliance on the main river channel and tributaries in the Fitzroy River. Differences in the main species utilised in the

\footnotetext{
${ }^{1}$ Principal Research Scientist, CSIRO Ecosystem Sciences, PMB 44, Winnellie NT 0822. Corresponding author: sue.jackson@csiro.au Tel: +618 89448415. Fax: +618 89448444 .

${ }^{2}$ CSIRO Ecosystem Sciences, PMB 44, Winnellie NT 0822.

${ }^{3}$ CSIRO Ecosystem Sciences, PMB 44, Winnellie NT 0822.
} 
two catchments appear strongly related to habitat use, with 4 of the 5 most commonly harvested species in the Daly catchment non-fish species associated with billabong habitats, including Long-necked Turtle and Magpie Geese. Commonly harvested species from the Fitzroy catchment included small bodied species used as bait to catch other fish and two popular food species encountered in the catchment, Black Bream (Hephaestus jenkinsi) and Catfish (Neoarius spp.). Our results suggest that indigenous subsistence strategies are vulnerable to changes in the condition of the natural systems that provide the "ecosystem goods", particularly the annual inundation of floodplains that drives productivity and provides habitat for some of the key species. Water resource developments, such as river regulation and increased abstraction for irrigated agriculture, could adversely affect a highly valued customary component of the indigenous economies of tropical Australia.

\section{Keywords:}

Customary resource use, subsistence hunting and fishing, bush tucker, Australian indigenous peoples, aquatic resource management.

\section{INTRODUCTION}

The importance of wild resources to indigenous livelihoods is widely acknowledged in the literature on sustainable development and hunter-gatherer societies, including artisanal fisheries (Altman 2004; Usher and Wenzel 1987). Berkes (1990), for example, describes the existence of a significant and largely unrecorded indigenous subsistence fishery in Canada, with implications for public policy regarding resource management, allocation, impact assessment and regional economic planning. 
Highly productive ecosystems such as estuaries and floodplains provide multiple ecosystem goods and services upon which local communities depend (Barletta and Costa 2009). Yet globally many artisanal fisheries and other wild resource stocks are experiencing increasing pressure from human exploitation, habitat disturbances, and degradation (Baird and Flaherty 2005) and reports of the social and economic hardships impacting people in resourcedependent communities are increasing (Brooks et al. 2008; Garaway 2005; FAO 2004; Kent 1998).

In Australia, indigenous people value aquatic ecosystems in a number of inter-related ways. Aquatic ecosystems provide foods, art and craft materials and medicines for customary use and constitute part of a socially and culturally significant landscape. Being of considerable symbolic importance in local belief systems, fish and other aquatic species are also a source of cultural inspiration. Furthermore, the act of fishing performs a critical role in maintaining social relations and the transfer of cultural practices and is influential in affirming indigenous identities.

A 2008 National Aboriginal and Torres Strait Islander Social Survey (NATSISS) asked indigenous Australians about cultural practices including the harvest of wild resources. The results suggested that approximately $60 \%$ of indigenous people over 15 had participated in the harvest of wild resources in the past 12 months, and in remote communities that number increased to $72 \%$ (Altman et al. in press). In north Australia, customary fishing, hunting and harvesting activities contribute substantially to local food security through improved protein supply for domestic consumption (Altman 1987), although these activities are rarely included in fisheries statistics nor monitored or quantitatively assessed in any systematic fashion. Detailed regional studies have highlighted the contribution that customary use of wild 
resources can make; these include studies of the Dampier Peninsula in Western Australia (Buchanan et al. 2009), Cape York Peninsula in Queensland (Asafu-Adjaye 1996) and the Maningrida region in the Northern Territory (Altman 1984; 1987). Research by AsafuAdjaye (1996) in Queensland's Cape York region showed that most indigenous people participated in customary production for food, utensils, fuel, medicines and arts and crafts. Customary production was very significant in meeting nutritional needs in that region (where wild resources represented around $80 \%$ of their protein).

Indigenous land owners therefore have a strong interest in river health; affecting their ability to exercise their native title rights to wild aquatic resources. There is also the potential for these ecosystems to contribute further to rural livelihoods by sustaining future water-related businesses and employment, particularly commercial wildlife and bush-food ventures. The customary rights of indigenous Australians to natural resources have been accorded greater recognition by state management systems since the Native Title Act 1993 and the High Court decision in $1999^{4}$. Further weight can be lent to indigenous subsistence rights by a number of international legal instruments which recognise their rights to utilise and manage natural resources (e.g. the concept of sustainable use is supported in the United Nations Declaration on the Rights of Indigenous Peoples which was endorsed by the Australian Government in 2009).

Notwithstanding modest advances in legal recognition, there has been relatively little quantitative research on indigenous use of natural resources (see Buchanan et al. 2009; Venn and Quiggin 2007; Altman 1987). The area remains understudied despite the longevity of indigenous occupation of the Australian continent and the formal recognition of limited

\footnotetext{
${ }^{4}$ The Yanner $v$ Eaton High Court judgment of 1999 tested the legal significance of s.211 of the Native Title Act and found that the vesting in the crown of property rights in wildlife did not extinguish native title (Altman and Cochrane 2005).
} 
property rights afforded indigenous claimants by the common law and legal decisions (Jackson and Altman 2009; Langton et al. 2006). There is the small number of economic studies of the value of 'bush tucker' ${ }^{5}$ referred to above, as well as studies of its nutritional value (see Brimblecombe 2007; Lee et al. 1994; Rae et al. 1982). Ethno-biological studies of indigenous subsistence strategies in north Australia provide an important source of knowledge (see Prober et al. 2011; Bird et al. 2005; Walsh 1990; Williams and Hunn 1982; Meehan 1982; Chase and Sutton 1981; Gould 1969), as do investigations into the sustainability of indigenous wildlife harvesting strategies (see Wilson et al. 2010; Brook and Whitehead 2005; Griffiths et al. 2003). Concomitant with this interest is the focus on subsistence studies as a means of understanding socio-ecological interactions (Walsh et al. 2011; Holcombe et al. 2011; Russell- Smith et al. 1997).

Here we present the results of a three year study of indigenous socio-economic values relating to rivers, wetlands and other aquatic ecosystems undertaken with the cooperation of indigenous organisations in two large north Australian catchments. The benefits derived from subsistence use of tropical river systems are increasingly competing with water for agriculture and mining, river regulation for urbanisation and hydroelectric power, and may be adversely affected by the associated impacts of land use change on water quality (Douglas et al. 2011). Australia's tropical rivers generate approximately $60 \%$ of the country's surface runoff (CSIRO 2009). Drought and declining rainfall trends in southern Australia are driving renewed interest in exploitation of northern water resources, particularly for irrigated agriculture (Pusey 2011). Water storage would be an essential requirement for irrigation except where groundwater is available (Petheram et al. 2008). Expansion of water dependent industries that impact on flows, generate pollution or accelerate the spread of invasive species

\footnotetext{
${ }^{5}$ In Aboriginal English wild food resources are known as 'bush tucker'.
} 
poses distinct risks to indigenous societies in the region as their economic systems are reliant upon ecosystem goods and services (Finn and Jackson 2011) and their identities are affirmed by strong attachments to customary estates (Langton 2006).

Human dependency on the environmental resource base has been recognised in water resource planning in African and Asian countries for some years (King and Brown 2010; Matete and Hassan 2005). In South Africa for example, the water requirements of subsistence resource users are explicitly accounted for in water allocation decisions. Yet in north Australia, where the indigenous population is approximately $30 \%$ of the total, customary water uses are not prioritised in state water allocation systems (Jackson and Langton in press) and scientific studies undertaken by water resource agencies to mitigate the impacts of agricultural and industrial water consumption do not assess the pattern and significance of indigenous resource use (Finn and Jackson 2011).

In this region, governments have approved substantial industrial developments that have significantly affected the hydrological regime in the absence of comprehensive studies of the impacts on the indigenous subsistence economy. In some cases, indigenous communities have argued that these development activities have not coincided with their needs and values as they continue to seek a way of life that lies in some part outside the market economy (Altman 2004; Jackson 2006). In conducting this study we therefore sought to understand and reveal the 'invisible' customary component of two regional economies facing development. Working with indigenous communities in two catchments, we combined qualitative and quantitative methods over a three year period to understand the spatial and temporal pattern of aquatic resource use, its social, cultural and economic significance, and the water requirements of the wild aquatic resources consumed by indigenous households in case study 
locations.

This paper begins by outlining the theoretical debate we consider most relevant to indigenous customary resource use in the context of competing demands for water. In the section that follows, we describe the case study regions and methods employed in the study, highlighting key quantitative data relating to contemporary patterns of use. Relationships between patterns of indigenous resource use, available species, habitats and hydrology are discussed in the final section which also includes consideration of management implications.

\section{The Indigenous customary sector}

There is evidence that the coastal wetlands of north Australia have been continuously occupied since at least 50,000 BP (Russell Smith et al 1997). The pre-colonial pattern of indigenous economic life was based primarily on the availability of certain foods and game, climatic conditions, seasonal fluctuations, and food collecting, hunting and fishing activities (Russell Smith et al. 1997). Food was relatively more abundant in the tropical north than the arid centre.

Colonial and post-colonial policies consolidated indigenous populations and significantly disrupted subsistence strategies with consequences for health, well-being, economic development and cultural life (Keen 2004). Despite holding title to approximately $20 \%$ of the Australian land mass (Altman and Jackson 2008), much of which is relatively undisturbed and intact, today Australia's indigenous population lives in relative poverty (SCRGSP 2011). Indigenous Australians experience multiple sources of disadvantage, as evident in poor educational achievements, greater burden of ill-health and markedly shorter life expectancies (Burgess et al 2009). The development of sustainable livelihoods, particularly for rural and 
remote indigenous communities, is regarded as a key means of overcoming indigenous disadvantage through income growth and improvements to social welfare. The shape of development pathways, their potential alignment with indigenous cultural prerogatives and the extent to which indigenous people must engage with global markets remains, however, a source of considerable public and academic debate (see Pearson 2000; Altman 2006).

The research questions framing this study have been shaped by international sustainable livelihoods research and considerably refined by insights from Altman's analysis of Australian indigenous economic systems (Altman 2001; 2006). The livelihoods approach to development pioneered by Chambers and Conway (1992) and Scoones (1998) calls for greater appreciation of the diverse livelihood practices engaged in by rural households, including non-market activities. This approach attends to the ecological dependencies of rural livelihoods and the institutions which affect resilience or vulnerability to economic and/or environmental shocks and disturbances.

By hunting, fishing and harvesting wild resources indigenous people maintain important communal aspects of social and economic life based on cultural continuities. These widely practiced customary activities provide of a low-cost means of sustenance to supplement incomes dominated by social security entitlements. The customary sector also includes indigenous land and water management activities that preserve the health of habitats such as landscape burning, weed control and ritual practices that sustain the sanctity and productivity of cultural landscapes. In undertaking these activities, people maintain connections to landscapes that inspire artistic activity and other commercial opportunities such as cultural tourism and payment for environmental services (Altman 2006). 
Customary patterns of resource use are vulnerable to both the development (and environmental) policies of the state and the consequences of those policies if they result in the destruction of ecological and economic diversity. Such vulnerability is evident in Australia's Murray-Darling Basin where a minority indigenous population has been severely impacted by the environmental effects of over-use of water for irrigated agriculture and drought (Weir 2009). It is therefore imperative that the full socio-economic impact of water resource development decisions is assessed and not just the potential stimulus that increased water use for agriculture might provide to the market sector.

Altman's hybrid economic model (2001) is particularly well-suited to this study's context because it gives explicit attention to the non-monetised resource use and management activities that lie outside the market economy. Conventional economic frameworks tend to consider two sectors: the private (market) and public (state). The hybrid economy however includes a third sector, the customary sector, which accounts for the economic contribution that activities such as subsistence hunting make to indigenous production (Altman 2001). In remote Australia, the hybrid economy includes a significant state sector (welfare and state employment) whereas the market sector is often very small and might include the retail sector, the arts industry, commercial wildlife harvesting, local entrepreneurial activity and, in some situations, articulation with the mining and tourism sectors (Altman 2001). In Altman's model, the indigenous economy of any region encompasses overlapping market and customary (non-market) sectors and values.

The hybrid economy framework has been used principally as an analytic device to highlight the significance of the non-market sector and the extent of sectoral inter-linkages. It remains very difficult to quantify because of the non-market component. However, Altman (2006) 
suggests that the customary economy can have significant economic value, especially in the tropical savannas and wetlands. Nonetheless, when applied to the water sector, this device reveals vital interdependencies between water extracted from river systems (or the ground) to generate market value and water required to sustain aquatic ecosystems that generate nonmarket value, in addition to other market value such as tourism revenue. Jackson and Altman (2010) argue that the model is therefore useful in challenging the consumptive-'productive' vs non-consumptive-'unproductive' dichotomy that currently dominates water allocation planning in Australia ${ }^{6}$.

According to Jackson and Altman (2009, p.36), these 'sectoral overlaps and associated tradeoffs are crucially important in considering how water might be optimally used and how different value systems and property rights regimes might come into conflict over definition of that optimality'. The very different Western and indigenous customary views about water have inevitably created a degree of contestation about who holds primary authority over fresh water, and the power imbalance in favour of the non-indigenous majority population evident in Australia has affected the extent to which indigenous water uses are taken into account and protected by contemporary water management (Jackson et al. in press).

Elsewhere we have argued for adaptations to water planning methods, specifically environmental flow assessment techniques, to better account for linkages and dependencies between indigenous people and rivers (Finn and Jackson 2011). To this end, the study sought to describe the patterns of aquatic resource use and to quantify the flow requirements of species of value to indigenous people in two regions. Although the application of the results

\footnotetext{
${ }^{6}$ According to this approach, water used by the environment or people for recreation is considered to be nonconsumptive whereas water used for industry and other human purposes are considered to be consumptive.
} 
to environmental flow methods is presented elsewhere (Jackson et al. 2011; Woodward et al. 2012), it was anticipated that the results presented here would contribute to current water use decisions and provide a baseline for monitoring impacts over time.

\section{STUDY AREA AND METHODS}

\section{Study area}

The study area comprises two catchments in tropical north Australia: the Daly River catchment in the Northern Territory and the Fitzroy River catchment in Western Australia (see Figure 1). The catchments were selected as study sites because a survey of water agencies and stakeholders nominated them as amongst the most likely to face increases in water extraction (see www.track.gov.au) and water allocation planning was underway.

\section{Insert Figure 1 somewhere around here}

Northern Australia is mostly flat and consists of extensive, low, inward draining plateaus, which are situated behind narrow coastal plains (Petheram et al. 2008). More than $94 \%$ of the region's rainfall is received between November and April, generated by local convection and tropical cyclones (Cresswell et al. 2009). Mean annual rainfall across our study sites ranged from $540.5 \mathrm{~mm}$ in Fitzroy Crossing (WA) to $1354 \mathrm{~mm}$ at Mango Farm, Daly River (NT). Evapo-transpiration rates range between $700 \mathrm{~mm}$ in the cooler dry season and up to $1200 \mathrm{~mm}$ per year in the warm wet season, producing net annual water deficits (Cresswell 2009).

The Fitzroy River (Western Australia) has a catchment area of almost 94,000 $\mathrm{km}^{2}$ and a low mean annual discharge of 7,540 GL at Camballin Barrage, whereas the Daly River catchment 
(Northern Territory) covers just over $53,000 \mathrm{~km}^{2}$ and has a mean annual discharge at the Mount Nancar gauge of 8,184 GL (CSIRO 2009). Both rivers display distinct hydrological seasonality with most of their discharge occurring predominantly during the wet season (November to April), while inter-annual variation in the magnitude and timing of peak flows is high, particularly in the Fitzroy River (Kennard et al. 2010). During the dry season (May to October) flow in the main channel of the Daly River is sustained by groundwater inputs and is classified as perennial, whereas the Fitzroy River main channel ceases to flow and is classified as highly to extremely intermittent (Kennard et al. 2010). In this environment, permanent pools fed by groundwater provide crucial ecological refuges during exceptionally hot, dry conditions. Tributaries in both catchments range from perennial to extremely intermittent.

The floodplain area of the Fitzroy River catchment $(434,044$ ha) is much greater than the Daly River catchment $(74,463 \mathrm{ha})$ (D. Ward unpub. data) and the two catchments differ in their wet season hydrology. The Daly River typically overflows its banks and floods out to extensive, vegetated wetlands that hold water for 4-5 months before receding to permanent billabongs, whereas floods in the Fitzroy River may persist for only weeks and the floodplains do not develop distinct wetland vegetation (Jardine et al. 2011).

\section{Methods}

Data was collected for this research from the indigenous communities of Pine Creek and Naiuyu-Nambiyu in the Daly River region, and Noonkanbah and Fitzroy Crossing in the Fitzroy River region.

River use mapping 
Participatory mapping preceded the household survey to provide a detailed understanding of the distribution of harvesting sites, the species obtained from those locations and seasonal information on species availability and in some cases site hydrology. River use mapping enabled researchers to establish relationships with indigenous participants and provided much needed context for the information encountered during household surveys (for instance the wider social and cultural significance of key sites was sometimes revealed during these mapping exercises (see Toussaint 2010; Jackson et al. 2011).

\section{Household surveys}

In order to assess the full seasonal pattern of resource use, a total of 82 households were surveyed twice every three months over a two year period in 2009 and 2010 (i.e. 16 survey rounds). Surveys were implemented during 963 semi-structured interviews, with participants being asked to recall a period of subsistence activity from aquatic habitats over the preceding 2 weeks. Interviews were repeated twice in a month to allow for longer temporal coverage (i.e. 1 month) while reducing the overall recall period to 2 weeks. The length of interviews ranged from approximately 5 minutes to an hour depending on the amount of harvesting activity that had been undertaken in the previous 2 weeks.

Households participating in the survey were not selected at random. Due to the frequent timing of repetitive interviews and their potentially intrusive nature (Altman 1987), we asked survey communities to nominate households likely to be interested in participating. As per the snowball technique (Goodman 1961), households initially chosen were then asked to suggest another household to participate. To reduce bias, we requested that respondents nominate households known to harvest from different areas, or at different rates of intensity. Our purpose was to ensure survey respondents covered the range of harvesting activity and 
locations that were representative of the community more broadly.

A lack of quantitative information on flow related resource use by indigenous communities precluded the use of power analysis or a similar method to choose a sample size. Instead, we reviewed the international literature to calculate sample sizes reported in peer-reviewed publications. Sample size ranged from 3\% (acknowledged as small by Gray and Altman (2006)) to $20 \%$, which was considered desirable for large communities (more than 200 households) (Turner 1998; Shackelton et al. 2007). We aimed at a sample size that was as large as logistically possible given resource and time constraints, and that reflected a number of samples seen as appropriate in published literature. In the Daly River catchment, the average number of households surveyed was 24; representing approximately $23 \%$ of indigenous households. The average number of households surveyed in the Fitzroy River was 36 ; a sample size of approximately $20 \%$.

The surveys were conducted as a semi-structured interview where the researcher asked a series of questions on harvesting activity. Although there were set questions and a field data sheet to complete, the researcher was free to ask the questions in whichever order encouraged the best participant recall of harvesting activity. During each household interview, participants were asked to separately discuss each harvesting trip, allowing researchers to calculate the number of species and individuals being collected by trip, and align this information to specific locations and habitats. Participants were also asked to provide: trip location, habitat visited, number of people present, species and method of capture, quantities harvested, final use of the species, and whether the harvest was shared.

Validation 
Indigenous harvest surveys present a number of limitations common to self-reporting fisheries methodologies, including strategic bias and recall failure. Berkes (1990) has noted the problems associated with the quantification of subsistence fisheries, however, he concluded that harvest values reported in Canadian questionnaires were reliable if not conservative estimates. The survey instrument used in this study was validated using a number of techniques to ensure the information being recorded was as accurate as possible. Prior to the study, the survey instrument was trialled with respondents from both catchments to test participant understanding of the questions. The trial generated a list of habitats, locations and species (including their local names) that were encountered during interviews. The survey was modified and reviewed by the project steering committee consisting of ecologists and social scientists with expertise in human ecology.

During the two years of surveys, researchers kept a field journal that contained critical reflections on the conduct of surveys. Information from a small number of surveys and a single survey participant were excluded from the final dataset after reflecting on comments recorded in field journals. The data from a resource mapping exercise (reported in Jackson et al. 2011) and a substantial record of local ecological knowledge, represented in a series of seasonal calendars (Woodward et al. 2012; http://www.csiro.au/resources/Ngangi-SeasonalCalendar.html), was also used to inform the interpretation of quantitative data on household aquatic resource use. Finally, researchers took opportunities to be involved in direct observation of hunting activities to ensure their knowledge of harvesting activity was sufficient to critically appraise information returned during interviews.

Notwithstanding these attempts made to validate the data, we highlight a further limitation to this study. The results are applicable to the studied communities given the climatic, social and 
environmental conditions encountered during 2009 and 2010. Additional research is required to gain a fuller understanding of indigenous resource use patterns across the entire tropical north, and whether our results are typical and therefore can be extrapolated to other similar contexts. Significant inter-annual variability in flows calls for the collection and consideration of data over longer periods of time to account for the variable nature of interannual discharge and floodplain inundation in Australia's north.

\section{RESULTS}

Men, women and children of the households surveyed collected a wide variety of aquatic animal species including fish, sharks, crustaceans, crocodile eggs and plants including the roots, stems, fruits, bulbs, and pods. The full inventory of aquatic resources harvested presented in Table 1 shows that 42 species were harvested across both catchments, with 20 species being common to both.

Insert Table 1 around here

\section{Seasonal pattern of trips}

On average, survey respondents undertook 1.5 trips a fortnight in the Daly catchment and 1.4 trips a fortnight in the Fitzroy. Trip frequency in the two study catchments revealed a highly distinct seasonal pattern (Figure 2). The frequency of harvesting trips was at its lowest in the Daly catchment during the wet season ${ }^{7}$ when high floodwaters reduced access to key sites, while trip frequency was at its highest during the wet season in the Fitzroy catchment (Figure

\footnotetext{
${ }^{7}$ As noted by Altman (1984) and others (e.g. Russell-Smith et al. 1997), indigenous people do not merely distinguish between the 'wet' and 'dry' seasons, as do most non-indigenous residents of tropical north Australia, but divide the year into a far greater number of seasons. Indigenous seasonal knowledge in the study areas is described in Woodward et al. (2012).
} 
2). In the Daly River during the wet season, survey respondents continue to fish in the floodwaters surrounding their communities, but much of the country they usually visit by vehicle is either completely inundated, or cut off by flooding (Plate 1). During our household surveys at the height of the wet season in 2009 and 2010 in the Daly River, $45 \%$ of respondents stated that they had not been fishing because "the water is too high", the roads or banks were "too boggy" or the river was "running too hard", compared to a similar response from only $8 \%$ of survey respondents in the Fitzroy (Jackson et al. 2011).

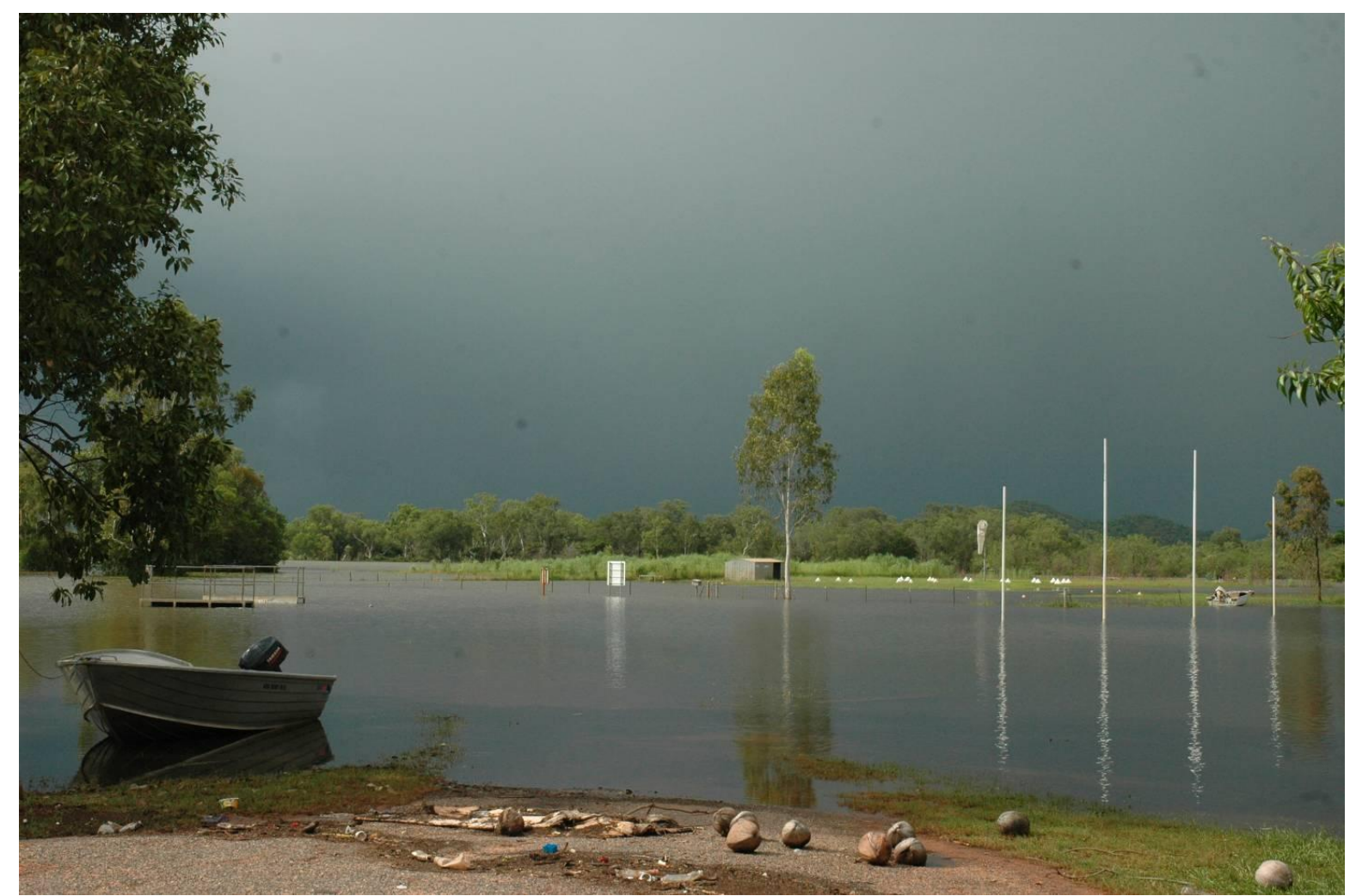

Plate 1: The Australian Rules football field and skate ramp in Nauiyu-Nambiyu community adjacent to the Daly River during February 2009. Access to the community is only by boat during the height of the wet season.

\section{Insert Figure 2 somewhere around here}

While harvesting locations are also isolated by floodwaters in the Fitzroy catchment, flooding in the Fitzroy and Margaret rivers stays largely within the river channel (Plate 2). This provides our survey respondents, most of who live within walking distance of the river 
channel, with ready access to the river. This period is well known as an excellent time to catch Barramundi (Lates calcarifer) and Catfish (Neoarius spp.) at locations where flooded creeks are running back into the river. Fitzroy River survey respondents often commented on people "going mad for Barramundi" at this time, and so the fishing effort was substantial (Figure 2).

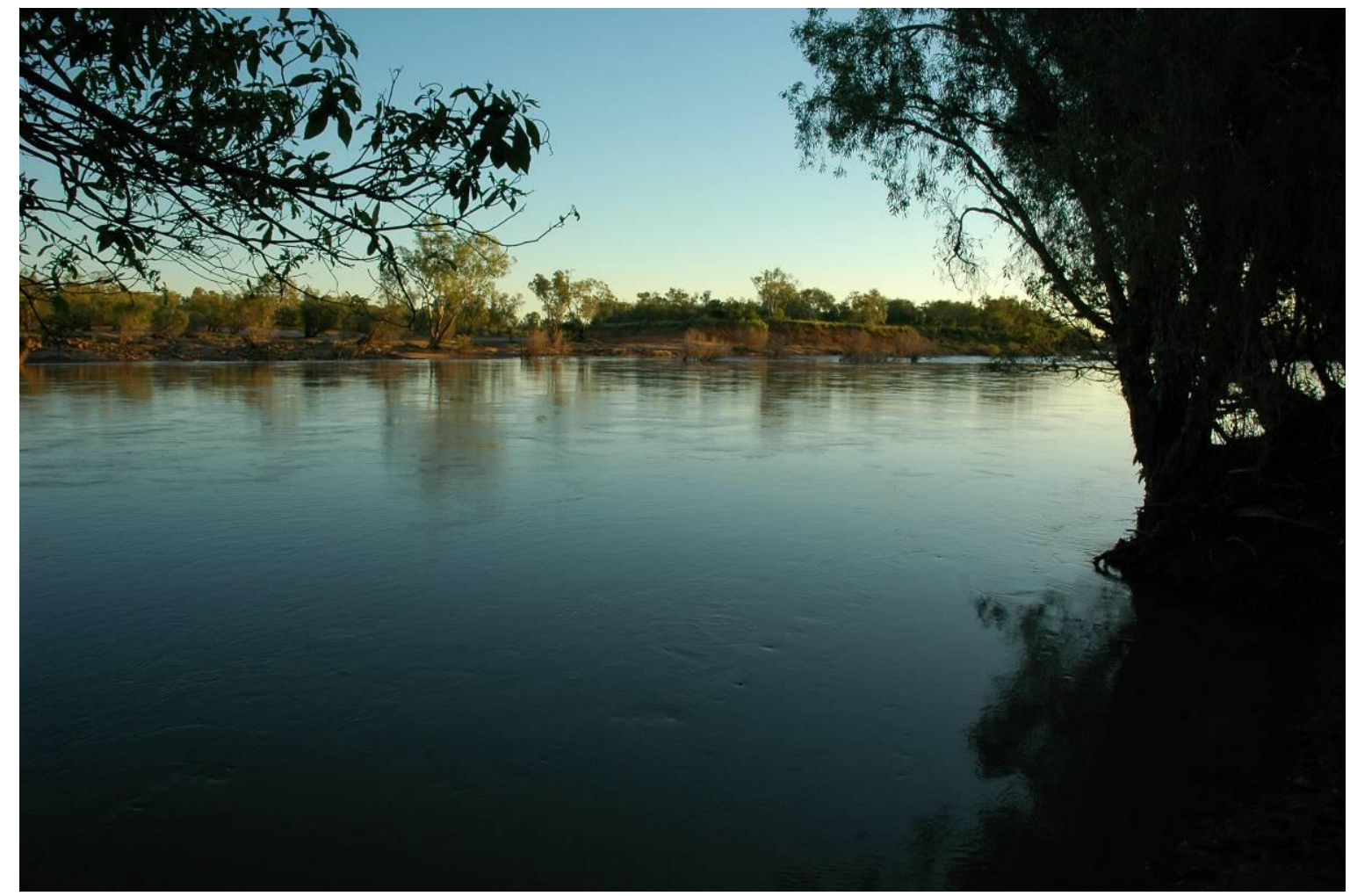

Plate 2: The Fitzroy River running near a bank-full flow near Yungngora community; upstream of Camballin Barrage on 12 March 2009.

\section{Preferred habitats}

Substantial differences between catchments are evident in the way in which survey respondents used aquatic habitats throughout the year. Harvesting activities in the Fitzroy River were largely focussed on use of the main river channel where visits made up more than $70 \%$ of all trips, regardless of the season (Figure 3). Harvesting activities in the Daly, however, showed a clear switch from use of the river channel during the wet season to 
billabongs as the dry season continued. By the late dry season, $70 \%$ of all Daly trips were to billabongs, whereas at the same point in time in the Fitzroy, billabongs accounted for only $10 \%$ of trips (Figure 3). Spring-fed creeks made up a relatively consistent proportion of site visits in the Daly River (ranging from 5-11\%), but were rarely used in the Fitzroy due to their more limited availability (Figure 3).

Insert Figure 3 around here

\section{Species caught and consumed in highest numbers}

\section{Insert Figure 4 around here}

Long-necked Turtle (Chelodina rugosa) were the species harvested and consumed in the highest numbers in the Daly catchment (Figure 4a) with approximately 2200 harvested during the survey period. In this catchment, four of the five species harvested in the greatest numbers were non-fish species, with Black Bream (Hephaestus fuliginosus) the only fish species to be harvested in numbers sufficient to make the top five. Lotus Lily (Nelumbo nucifera) seeds taken from wetlands in the Daly River catchment were the only aquatic plant matter to be harvested from either catchment in a substantial quantity. Four of the five species harvested in the highest numbers in the Fitzroy catchment were fish species (Figure 4b). Two of these fish species, Bony Bream (Nematalosa erebi) and Spangled Perch (Leiopotherapon unicolour), are small bodied species predominately used as bait for catching other fish. Black Bream (Hephaestus jenkinsi) and Catfish (Neoarius spp.) are two popular food species (Toussaint 2010), and were harvested in relatively high numbers.

Two species harvested in high numbers in the Daly River catchment showed a distinctly seasonal pattern of harvest. Long-necked Turtle (Figure 5a) and Magpie Goose (Anseranas 
semipalmata) (Figure 5b) were harvested in substantially higher numbers late in the dry season than they were in the wet or early dry seasons.

Insert Figure 5 around here

\section{Intra and inter-community distribution of wild resources}

Our results show that the household consumption of species was always lower than the amount harvested (Figure 6). This is indicated clearly in the Daly River (Figure 6a) where $66 \%$ of Spangled Perch harvested are consumed by the survey household, while only $19 \%$ of harvested Long-necked Turtles are consumed by the survey household. Many larger species, particularly species capable of surviving for weeks after capture, such as Long-necked and Short-necked Turtle, and other species such as Barramundi and Magpie Goose, are shared extensively. Black Bream appear to fill an intermediate role, where some sharing is common, but they are also immediately eaten. A similar, albeit less evident, pattern was observed in the Fitzroy River (Figure 6b). Large species such as Freshwater Sawfish (Pristis microdon) (43\% consumed), Barramundi (45\% consumed) and Long-neck Turtle (37\% consumed) were frequently shared, while "snack" and bait species such as Spangled Perch (60\% consumed), Black Bream (53\% consumed), Cherabin (57\% consumed) and Freshwater Mussels (70\% consumed) were more commonly consumed within the household.

Insert Figure 6 around here

\section{DISCUSSION}


The subsistence activities of indigenous people are determined in part by the spatial and temporal distribution of aquatic resources, which is in turn driven by the flow regime. Livelihood patterns provide confirmation of the critical role of seasonal wetting and drying in shaping the social-ecological system. Communities respond to the annual cycle of flows following the seasonal regime of flooding and falling waters. The landscapes of the Daly and Fitzroy regions do however differ in the extent of persistent floodplain and wetland habitat (referred to as billabong habitat in Figure 3) available to subsistence use. As a result, there are clear differences in the patterns of resource use by indigenous people in our two study catchments.

Firstly, the temporal distribution of harvesting trips differed between the two catchments, with trips being conducted much more frequently during the wet season in the Fitzroy catchment. This appeared partly related to access to habitats; movement in the Daly River catchment was constrained when respondents became completely isolated during the wet season, whereas in the Fitzroy, lengths of the river channel remained relatively accessible. It appears that the different flooding regimes of the two rivers, and the greater propensity for the Daly River to "break its banks" resulting in overbank flow and a longer period of inundation (Jardine et al. 2011), influenced the temporal pattern of indigenous resource use. Inundation in the Daly in 2008, the first year of data collection, lasted around four months whereas floodplain inundation lasted only three weeks in the Fitzroy catchment (ibid).

Secondly, the distribution of harvesting trips among habitat types also differed between the two catchments. Survey results from the Daly showed that hunters/fishers had a much greater propensity to visit and use extensive floodplain and billabong habitats than did those in the Fitzroy catchment. While the river channel was consistently the main habitat used in the 
Fitzroy, fishing and harvesting patterns in the Daly show that even when the river channel is at its most popular in the wet season, only $44 \%$ of respondents visited in comparison to the Fitzroy, at which time $72 \%$ of people visited this environment. Daly River communities also spent more time using spring-fed creeks than those from the Fitzroy. Springs are more prevalent in the Daly than the Fitzroy; discharge from springs and more diffuse river bed groundwater discharge accounts for most the total dry season flow in the Daly, particularly towards the end of the season (CSIRO 2009).

Thirdly, the availability and distribution of key species appears to be a major driver explaining the pattern of harvesting activity in each of our study catchments. The very clear switch from the river channel (in the wet and early dry seasons) to billabongs (in the late dry season) suggests that indigenous people in the Daly are targeting rich environments that present harvesting opportunities not available to the residents of the Fitzroy who are more constrained in their choice of locations. There is further evidence for this interpretation when one considers that the main channel of the Daly River is permanently flowing and fed by extensive groundwater discharge throughout the dry season, while the Fitzroy River ceases to flow entirely during the late dry season in many years. Survey respondents from the Daly can therefore choose between river channel and floodplain in the late dry season and it is the resource rich wetlands on the floodplains and the associated high densities of valuable food species that they target (Jackson et al. 2011), rather than the river channel which still provides suitable habitat for other species.

The Daly River catchment contains much more seasonally inundated floodplain and billabong habitat than the Fitzroy (Jardine et al. 2011) and this land is accessible under current institutional arrangements. Key sites are found on land held under Aboriginal 
freehold title, or land leased to pastoralists with whom indigenous people have negotiated access rights. Four of the five species caught in the highest numbers in the Daly catchment are readily caught from billabong habitats, with two of these four being iconic 'high value' species with a life history tightly linked to billabongs. Here we define 'high-value species' as those species for which the replacement cost is high, calculated by estimating the market price of a proxy bought from a grocery store to replace the wild resource. For a full discussion of the methods and assumptions involved in the economic valuation see Jackson et al. (2011).

Late in the dry season, many of the billabongs in the Daly River begin to dry. Adult Longnecked Turtle aestivate in the mud of drying billabongs until the floodplain is inundated in the following wet season. During this aestivation period, people search the billabongs, pushing long, narrow sticks into the mud until they feel a turtle shell (see also McGregor et al. 2010). Turtles are then dug out and can be cooked immediately, or kept alive for a period of time for later consumption, or shared with relatives and other families.

Likewise, Magpie Geese are also very abundant in the Daly late in the dry season as they move into drying billabongs to feed. Magpie Geese are available in the Fitzroy catchment but are much less abundant, with the Northern Territory having the largest Australian population of the species (Delaney et al. 2009). Magpie Geese migrate from their nesting areas on flooded wetlands to feeding areas late in the dry season, and predictably "arrive" at many of the billabongs along the Daly River during this period (P. Bayliss pers. comm.). The substantial increase in harvest per trip of Magpie Geese reflects their availability at harvest sites. Indigenous people shoot, exchange or eat them in large numbers at this time of year, and so it is a popular time to undertake harvesting trips to billabong habitats. The abundance 
of target, or 'high value' species (Jackson et al. 2011), strongly influenced the timing, location and volume of harvest/catch of our survey participants.

Not only were particular 'high value' species targeted, but they were hunted at times when they were in the best condition for eating. For example, turtles, and other aquatic species, such as catfish and black bream, were targeted for hunting by indigenous research participants when they are known to be 'fat', with 'skinny' animals sometimes rejected and returned to the water (Woodward et al. 2012). A preference by indigenous people for 'fatness' in wild resources has previously been documented, with the seasonal shifts in harvesting strategy often reflecting the degree of fat in the species concerned (Rouja et al., 2003; Altman 1987). Although wild aquatic resources consumed by indigenous people in our study catchments are not traded in a formal market, sharing of resources is substantial (Toussaint 2010) and anecdotal comments made during the course of the project suggests that the distribution of 'high value' species through food-sharing networks extends some hundreds of kilometres from the case study communities (Jackson et al. 2011; Toussaint 2010). It is therefore quite plausible that indigenous people in these areas have developed sharing systems to stabilise their food intake and incomes by sharing the risk of low catches (van Oostenbrugge, van Densen and Machiels 2004).

Regional studies also lend support to the finding that indigenous people in the Daly are targeting rich environments that present harvesting opportunities not available to the survey respondents in the Fitzroy. A study of the nearby West Arnhem region of the Northern Territory found that although aquatic and semi-aquatic habitats (floodplains, swamps and streams) made up only $15 \%$ of the regional area, they were the location of $79 \%$ of all hunting and gathering trips (Griffiths 2003). Returns per hunting trip ranged from $2-7.5$ animals in 
aquatic habitats as opposed to $<1$ animal per trip in terrestrial habitats (ibid). Altman (1984) conducted research in the same area and found that the main determinant of seasonal movements was the availability of subsistence resources at different locations (or 'resource bases'), noting that the heavy hunting of the 'massive' Magpie Goose concentrations in the late dry season illustrated the process of selective species utilisation: 'The seasonal reliance on particular faunal categories is primarily due to conscious decisions made to exploit particular species at particular locations' (Altman 1984: 40).

In weighing up the role played by various components of traditional economic life of indigenous people, Walsh (1990) argues that it is more helpful to consider that subsistence activities were constrained rather than determined by the environment. These constraints varied according to the relative richness of the environment. Coastal and floodplain environments were very productive zones (see also Barletta and Costa 2009), whereas arid zones were less so, imposing sometimes severe constraints on indigenous life (Naughton, O'Dea and Sinclair 1986). For indigenous groups such as the desert-dwelling Martu, the 'location and degree of permanency of water sources limited or expanded the tracts of country' to be exploited and their distribution was a key factor that influenced Martu movement over the year (Walsh 1990: 27).

Conclusively proving that the abundance of 'high-value' species is a key determinant of subsistence strategies requires consideration of a large number of interacting factors beyond the scope of this study, including land tenure and rights to access natural resources, knowledge of seasons, economic considerations such as the availability of vehicles and harvesting technology, social and cultural prerogatives, nutritional characteristics and the amount of time available for the subsistence activities after meeting commitments to family 
and paid work. Veth and Walsh (1988) propose several key variables that determine the significance or relative contribution of a species to the total diet: the abundance, predictability and accessibility of each species, the energy costs of processing each species, the energy and nutrient returns of each species and cultural preferences. Although we do not consider all these, the data presented here do suggest that the abundance, predictability and seasonality of species availability are strong drivers of subsistence use strategies.

\section{Management Implications and Synthesis}

The patterns of resource use described in this paper provide further support for the hypothesis that indigenous harvest of aquatic species is strongly linked to existing flow regimes, and is likely to be substantially affected by flow alterations that modify habitat availability and species distributions. Although not a significant direct user of water, the customary sector is clearly dependent on aquatic biodiversity and the regions' flow ecology. Emerging research suggests that alterations to these rivers' flow regime under future irrigated agricultural development scenarios could have a substantial impact on populations of species that contribute to the indigenous customary economy (Chan et al. 2012). An increased use of either surface or groundwater from the Daly River catchment in the dry season could, for example, put at risk certain fish species that rely on an interconnected river system, including Black Bream which is popular with indigenous fishers. Our investigations demonstrate that access to the aquatic habitats supporting species of economic importance to indigenous people, and the maintenance of the seasonal wetting and drying that determines their availability, are critical to maintaining a vibrant customary economy. It is therefore critical for water allocation plans to be underpinned by a sound understanding of the composition of the indigenous customary harvest and its spatial and temporal patterns. 
We argue that by more clearly understanding aquatic resource use and framing that knowledge within a hybrid economic model, a vital sphere of economic activity and its sociocultural significance is more fully revealed to decision-makers. Further, this model allows for a more comprehensive, systematic consideration of the multiple socio-economic impacts of competing water uses (water resource development vs. aquatic habitat use) that will likely be unevenly distributed across social groups.

A likely trajectory of change under a future development scenario in north Australia would result in some removal of water from aquatic systems for the irrigation of crops, and other commercial uses. Theoretically at least, the aim of this form of development would be to increase commercial production by growing the region's market sector. By considering the impact on development pathways on the three economic sectors of the hybrid economy, one is able to scope more thorough inquiries into the trade-offs between water use options under given governance arrangements and to better understand the drivers of change. For example, will farming benefit an indigenous community that is not employed in agriculture, does not own local enterprises, holds no (recognised) property in water but is heavily engaged in the customary sector which is aligned well to cultural prerogatives? Should agricultural development result in reduced availability of key aquatic species, what effect might a decline in indigenous harvests have on household budgets and householder ability to consume market goods and services from non-indigenous enterprises? What effect might this have on state welfare budgets? Assuming that indigenous farm-based employment was to grow under a specific water use scenario, might this stimulate customary activity by improving access to boats, vehicles and more efficient fishing gear and thereby place greater pressure on particularly vulnerable species? 
We are not in a position to precisely answer these and other similar questions given gaps in empirical knowledge which constrain our ability to quantify the potential effect of water use decisions and any consequent flow alterations on the economic value of indigenous wild resource harvest. However conceptual models of the indigenous economy can assist in considering and balancing the likely influence of impacts on indigenous livelihoods. Sustainable water resource development pathways will require in the first instance, a clear understanding of the indigenous values associated with aquatic resources as well as the flow requirements of these species. Allocating or protecting flows to minimise impacts on indigenous communities cannot occur effectively without such knowledge. The results presented here and in Jackson et al (2011) provide data on indigenous wild resource harvest in two catchments facing changes to water consumption brought about by agricultural expansion and land use intensification, and so can serve as a baseline for long term monitoring of socio-economic impacts

\section{ACKNOWLEDGMENTS}

The paper is based on research conducted under a large multi-disciplinary research program, the Tropical Rivers and Coastal Knowledge Research Hub (TRaCK). TRaCK receives major funding for its research through the Australian Government's Commonwealth Environment Research Facilities initiative; the Australian Government's Raising National Water Standards Program; Land and Water Australia; the Fisheries Research and Development Corporation and the Queensland Government's Smart State Innovation Fund.

The authors would also like to acknowledge the contributions of indigenous traditional owners in the Daly, Katherine and Fitzroy River regions of north Australia. Representing 
traditional owners from these regions, the Northern Land Council and the Kimberley Land Council have both supported the research described in this paper. Constructive input has been provided on various aspects of the research by Jon Altman, Michael Douglas, Brad Pusey, Mark Kennard, Natalie Stoeckl, Emma Woodward, Adam Liedloff, Alan Andersen, Marcus Barber, Tony Griffiths, Sandy Toussaint and Geoff Buchanan. The paper has also benefited from comments by Glenn Harrington, Michael Douglas, Peter Bayliss and the three anonymous reviewers. Any errors and omissions are the responsibility of the authors. 


\section{REFERENCES}

Altman, J.C (1984). The dietary utilisation of flora and fauna by contemporary huntergatherers at Momega Outstation, north-central Arnhem Land. Australian Aboriginal Studies 1: 35-46.

Altman, J.C. (1987). Hunter gatherer's today: an Aboriginal economy in north Australia, Australian Institute of Aboriginal Studies, Canberra.

Altman, J.C. (2001). Sustainable development options on Aboriginal land: the hybrid economy in the twenty-first century, Centre for Aboriginal Economic Policy Research, Australian National University, Canberra, ACT.

Altman, J.C. (2004). Economic development and Indigenous Australia: contestation over property, institutions and ideology. Australian Journal of Agricultural and Resource Economics 48: 513-534.

Altman, J.C. (2006). The Indigenous hybrid economy: A realistic sustainable option for remote communities? In Australian Fabian Society, Melbourne.

Altman, J.C., Biddle, N. and Buchanan, G. (In press). The Indigenous hybrid economy: Can the NATSISS adequately recognise productive difference?. In Hunter, B., and Biddle, N. (eds.). Social Science Perspectives on the 2008 National Aboriginal and Torres Strait Islander Social Survey, ANU E Press, Canberra. 
Altman, J.C., and Branchut, V. (2008). Freshwater in the Maningrida region's hybrid economy: intercultural contestation over values and property rights. Centre for Aboriginal Economic Policy Research, Australian National University, Canberra.

Altman, J.C. and Cochrane, M. (2005). Sustainable development in the indigenous-owned savannah: Innovative institutional design for cooperative wildlife management. Wildlife Research 32: 473-480.

Altman, J.C., and Jackson, S. (2008). Indigenous Land and Sea Management: Recognise, Respect and Resource. In Lindenmayer, D., Dovers, S., Harriss Olson, M., and Morton, I. (eds.), Ten Commitments: Reshaping the Lucky Country's Environment, CSIRO Publishing, Melbourne, pp. 207-214.

Asafu-Adjaye, J. (1996). Traditional production activities and resource sustainability: the case of Indigenous societies in Cape York Peninsula, Australia. International Journal of Social Economics 23: 125-135.

Baird, I.G., and Flaherty, M.S. (2005). Mekong River Fish Conservation Zones in Southern Laos: Assessing Effectiveness Using Local Ecological Knowledge. Environmental Management 36: 439-454.

Barletta, M., and Costa, M.F. (2009). Living and non-living resources exploitation in a tropical semi-arid estuary. Journal of Coastal Research, SI 56, Proceedings of the $10^{\text {th }}$ International Coastal Symposium. Portugal Lisbon, pp. 371-375.

Berkes, F. (1990). Native Subsistence Fisheries: A Synthesis of Harvest Studies in Canada. 
Arctic 43: 35-42.

Bird, D.W., Bliege, B. R. and Parker, C.H. (2005). Aboriginal burning regimes and hunting strategies in Australia's Western Desert. Human Ecology 33: 443-464.

Brimblecombe, J. (2007). Enough for rations and a little bit extra: Challenges of nutrition improvement in an Aboriginal community in North-East Arnhem Land. $\mathrm{PhD}$ thesis. Menzies School of Health Research and Institute of Advanced Studies, Charles Darwin University, Darwin.

Brook, B.W., and Whitehead, P.J. (2005). Sustainable harvest regimes for magpie geese (Anseranas semipalmata) under spatial and temporal heterogeneity. Wildlife Research 32: 459-464.

Brooks, S.E., Reynolds, J.D and Allison, E.A. (2008) Sustained by Snakes? Seasonal Livelihood Strategies and Resource Conservation by Tonle Sap Fishers in Cambodia. Human Ecology 36: 835-851.

Buchanan, G., Altman, J.C., Arthur, B., Oades, D., and Bardi Jawi Rangers (2009). "Always part of us": The socioeconomics of Indigenous customary use and management of dugong and marine turtles - a view from Bardi and Jawi sea country, Western Australia. Centre for Aboriginal Economic Policy Research, Canberra.

Burgess, C.P., Johnston, F.H., Berry, H.L., McDonnell, J., Yibarbuk, D., Gunabarra, C., Mileran, A. and Bailie, R.S (2009) Healthy country, healthy people: the relationship between 
Indigenous health status and "caring for country". Medical Journal of Australia 190: 567572.

Chambers, R., and Conway, G. (1992). Sustainable Rural Livelihoods: Practical Concepts for the 21 st Century, Institute of Development Studies, University of Sussex, Sussex.

Chan, T., Hart, B., Kennard, M.J., Pusey, B.J., Shenton, W., Douglas, M., Valentine, E. and Patel, S. (2012). Bayesian network models for environmental flow decision making in the Daly River, Northern Territory, Australia. River Research and Applications 28: 283-301.

Chase, A. and Sutton, P. (1981) Hunters and gatherers in a rich environment: Aboriginal coastal exploitation in Cape York Peninsula. In Keast, A. (ed.), Ecological Biogeography of Australia, Dr Junk, London, pp. 1818-1852.

CSIRO (Commonwealth Scientific and Industrial Research Organisation) (2009). Water in the Timor Sea Drainage Division. A report to the Australian Government from the CSIRO Northern Australia Sustainable Yields Project. CSIRO Water for a Healthy Country Flagship, Australia. $\mathrm{Xl}+508 \mathrm{pp}$.

Cresswell, R., Petheram, C., Harrington, I, Buetlikofer H., Hodgen, M., Davies, P., and Li, L. (2009). Water resources of northern Australia. In: Northern Australia Land and Water Science Review 2009, Publication Number INFRA-09155, Department of Infrastructure, Transport, Regional Development and Local Government, Canberra.

Delaney, R., Fukuda, Y. and Saalfield, K. (2009). Management program for the Magpie 
Goose (Anseranas semipalmata) in the Northern Territory of Australia, 2009-14. Northern Territory Department of Natural Resources, the Environment, the Arts and Sport, Darwin.

Douglas, M., Jackson, S., Setterfield, S., Pusey, B., Davies, P., Kennard, M., Burrows, D. and S. Bunn (2011). Northern futures: threats and opportunities for freshwater systems. In Pusey, B. (Ed.), Aquatic biodiversity in Northern Australia: patterns, threats and future, Charles Darwin University Press, Darwin: 203-220.

Finn, M.A., and Jackson, S. (2011). Protecting indigenous values in water management: a challenge to conventional environmental flow assessments. Ecosystems 14(8): 1232-1248. DOI 10.1007/s10021-011-9476-0.

FAO (2004). The State of World Fisheries and Aquaculture, 2000. Food and Agricultural Association, Rome.

Garaway, C. J. (2005). Fish, fishing and the rural poor: A case study of the household importance of small scale fisheries in the Lao PDR. Aquatic Resources, Culture, Development 1: 131-144.

Goodman, L.A. (1961). Snowball sampling. The Annals of Mathematical Statistics 32: 148170.

Gould, R.A. (1969). Subsistence behaviour among the Western Desert Aborigines of Australia Oceania 39: 253- 274.

Gray, M. and Altman, J.C. (2006) The economic value of harvesting wild resources to the 
Indigenous community of the Wallis Lake Catchment, NSW. Family Matters 75: 24-33.

Griffiths, A.D. (2003). Aboriginal hunting and its role in wildlife conservation for northern Australia. Third International Wildlife Management Congress, University of Christchurch, Christchurch, New Zealand.

Griffiths, A.D, Phillips, A. and Godjuwa, C. (2003). Harvest of Bombax ceiba for the Aboriginal arts industry, Central Arnhem Land, Australia. Biological Conservation 113: 295305.

Holcombe, S., Yates, P. and Walsh, F. (2011). Reinforcing alternative economies:selfmotivated work by central Anmatyerr people to sell Katyerr (Desert raisin, Bush tomato) in central Australia. Rangeland Journal 33:255-265.

Jackson, S. (2006). Compartmentalising culture: the articulation and consideration of Indigenous values in water resource management. Australian Geographer 37: 19-32.

Jackson, S., and Altman, J.C. (2009). Indigenous rights and water policy: perspectives from tropical northern Australia. Australian Indigenous Law Review 13: 27-48.

Jackson, S., Finn, M., Woodward, E. and Featherston, P. (2011). Indigenous socio-economic values and river flows. CSIRO Ecosystem Sciences, Darwin. 
Jackson, S. and M. Langton (In Press). Trends in the recognition of indigenous water needs in Australian water reform: the limitations of 'cultural' entitlements in achieving water equity. Journal of Water Law.

Jackson, S., Tan, P, Mooney, C., Hoverman, S. and White, I. (in Press). Principles and guidelines for good practice in Indigenous engagement in water planning. Journal of Hydrology: doi:10.1016/j.jhydrol.2011.12.015.

Jardine, T.D., Pettit, N.E., Warfe, D.M., Pusey, B.J., Ward, D.P., Douglas, M.M., Davies, P. and Bunn, S.E. (2011) Consumer-resource coupling in wet-dry tropical rivers. Journal of Animal Ecology doi: 10.1111/j.1365-2656.2011.01925

Keen, I. (2004) Aboriginal Economy and Society: Australia at the Threshold of Colonisation, Oxford University Press, South Melbourne.

Kennard, M.J., Pusey, B.J., Olden, J.D., Mackay, S.J., Steni, J.L, and Marsh, N. (2010). Classification of natural flow regimes in Australia to support environmental flow management. Freshwater Biology 55: 171-193.

Kent, G. (1998). Fisheries, food security and the poor. Food Policy 22: 393-404.

King, J., and Brown, C. (2010). Integrated basin flow assessments: concepts and method development in Africa and South-East Asia. Freshwater Biology 55: 127-146.

Langton, M. (2006). Earth, wind, fire, water: the social and spiritual construction of water in 
Aboriginal societies. In David, B., Barker, B., and McNiven, I. (eds.). The Social Archaeology of Australian Indigenous Societies, Aboriginal Studies Press, Canberra.

Langton, M., Mazel, O., and Palmer, L. (2006) The 'Spirit' of the Thing: The Boundaries of Aboriginal Economic Relations at Australian Common Law. The Australian Journal of Anthropology 17: 307-321.

Lee, A., O'Dea, K., and Mathews, J. (1994). Apparent dietary intake in remote aboriginal communities. Australian Journal of Public Health 18: 190-197.

Matete, M. and Hassan, R. (2005). An ecological economics framework for assessing environmental flows: the case of inter-basin water transfers in Lesotho. Global and Planetary Change 47: 193-200.

McGregor, S., Lawson , V., Christophersen, P., Kennett, R., Boyden, J., Bayliss, P., Liedloff, A., McKaige, B., and Andersen, A.N. (2010) Indigenous wetland burning: conserving natural and cultural resources in Australia's world heritage-listed Kakadu National Park. Human Ecology 38: 721-729.

Meehan, B. (1982). Shell Bed to Shell Midden, Australian Institute of Aboriginal Studies, Canberra.

Naughton, J., O’Dea, K. and Sinclair, G. (1986). Animal foods in traditional Australian or Aboriginal diets: Polyunsaturated and low in fat. Lipids 21: 684-690. 
Pearson, N. 2000. Our Right to Take Responsibility, Noel Pearson and Associates, Cairns.

Petheram, C., McMahon, T., and Peel, M. (2008). Flow characteristics of rivers in northern Australia: Implications for development. Journal of Hydrology 357: 93-111.

Prober, S.M., O'Connor, M.H. and Walsh, F.J. (2011). Australian Aboriginal peoples' seasonal knowledge: a potential basis for shared understanding in environmental management. Ecology and Society 16:12.

Pusey, B. (ed.) (2011). Aquatic biodiversity in Northern Australia: patterns, threats and future, Charles Darwin University Press, Darwin.

Rae, C.J., Lamprell, V.J., Lion, R.J., and Rae, A.M. (1982). The role of bush foods in contemporary Aboriginal diets. Proceedings of the Nutrition Society of Australia 7: 45-48.

Rouja, P.M., Dewailly, E., Blanchet, C. and Bardi, C. (2003). Fat, fishing patterns, and health among the Bardi People of North Western Australia. Lipids 38: 399-405.

Russell-Smith, J., Lucas, D., Gapindi, M., Gunbunuka, B., Kapirigi, N., Namingum, G., Lucas, K., Giuliani, P., and Chaloupka, G. (1997). Aboriginal resource utilization and fire management practice in western Arnhem Land, monsoonal northern Australia: Notes for prehistory, lessons for the future. Human Ecology 25: 159-195.

Scoones, I.(1998). Sustainable Rural Livelihoods. A Framework for Analysis, Institute of Development Studies, Brighton. 
Shackelton, C.M., Timmermans, H.G., Nongwe, N., Hamer, N., Palmer, N., and Palmer, R. (2007). Direct-use value of non-timber forest products from two areas on the Transkei wild coast. Agrekon 46: 135-156.

SCRGSP (Steering Committee for the Review of Government Service Provision). 2011. Overcoming Indigenous Disadvantage: Key Indicators 2011. Productivity Commission, Canberra. Retrieved 14 March 2012, from http://www.pc.gov.au/_data/assets/pdf_file/0018/111609/key-indicators-2011-report.pdf.

Toussaint, S. (2010). Fitzroy valley indigenous groups and the multi-criteria value of fishing and fish: a report for the social and economic values project (2.2) for Tropical Rivers and Coastal Knowledge (TRaCK), University of Western Australia, Perth.

Turner, C. (1998). Indigenous subsistence fishing survey kit - good fishing for the future, Queensland Department of Environment and Heritage, Balkanu, and Queensland Department of Primary Industry and Fisheries, Brisbane.

Usher, P.J. and Wenzel, P. (1987). Native harvest surveys and statistics: A critique of their construction and use. Arctic 40:145-160.

van Oostenbrugge, J.A.E., van Densen, W.L.T., and Machiels, M.A.M. (2004). How the uncertain outcomes associated with aquatic and land resource use affect livelihood strategies in coastal communities in the Central Moluccas, Indonesia. Agricultural Systems 82: 57-91.

Venn, T. and Quiggin, J. (2007). Accommodating indigenous cultural heritage values in 
resource assessment: Cape York Peninsula and the Murray-Darling Basin, Australia. Ecological Economics 61: 334- 344.

Veth, P. and Walsh, F. (1988). The concept of 'staple' plant foods in the Western Desert of Western Australia. Australian Aboriginal Studies 2: 19-25.

Walsh, F. (1990). An ecological study of traditional Aboriginal use of 'country': Martu in the Great and Little Sandy Deserts, Western Australia. Proceedings of the Ecological Society of Australia 16: 23-37.

Walsh, F. and Douglas, J. (2011). No bush foods without people: the essential human dimension to the sustainability of trade in native plant products from desert Australia. Rangeland Journal 33: 395-416.

Weir, J. (2009). Murray River country: An ecological dialogue with traditional owners, Aboriginal Studies Press, Canberra.

Williams, N.M. and Hunn, E.S. (1982). Resource Managers: North American and Australian Hunter Gatherers, Australian Institute of Aboriginal Studies, Canberra.

Wilson, G.R., Edwards, M.J. and Smits J.K. (2010). Support for indigenous wildlife management in Australia to enable sustainable use. Wildlife Research 37: 255-263.

Woodward, E., Jackson, S., Finn, M. and Marrfurra McTaggert, P. (2012) Utilising indigenous seasonal knowledge to understand aquatic resource use and inform water resource 
management in northern Australia. Ecological Management and Restoration 13(1): 58-64. doi: 10.1111/j.1442-8903.2011.00622.x 


\section{Tables}

Table 1: List of aquatic species and species groups harvested by indigenous survey respondents in the Daly and Fitzroy River catchments. Species with similar morphology that are potentially easy to misidentify have been grouped.

\section{Figures}

Figure 1: Map of northern Australia, showing the Fitzroy River and Daly River catchments.

Figure 2: Number of surveys completed in each season (bars) and the mean number of trips per survey (per fortnight) (+/- SE) for survey households in the Daly River (a) and Fitzroy River (b) catchments. Colouration of the bars reflects the number of surveys where respondents declared they went on " 0 " (white), between 1 and 5 (grey) or more than 5 (black) trips in the previous fortnight.

Figure 3: Percentage of hunting trips visiting habitats in the Daly and Fitzroy River catchments.

Figure 4: The ten species harvested in greatest numbers by household survey respondents from (a) the Daly River catchment and (b) the Fitzroy River catchment.

Figure 5: Mean number (+/- SE) of (a) Long-necked Turtle and (b) Magpie Goose harvested per trip by survey households in the Daly River catchment.

Figure 6: Harvest and consumption of the ten species captured in the highest numbers by 
survey households in (a) the Daly River and (b) the Fitzroy River catchment. "Harvest" is the total number of individuals of a species harvested by all people involved in the trip, while "consumption" represents the number of species consumed by the survey households or used as bait.

\section{Plates}

Plate 1: The Australian Rules football field and skate ramp in Nauiyu-Nambiyu community adjacent to the Daly River during February 2009. Access to the community is by boat during the height of the wet season.

Plate 2: The Fitzroy River running near a bank-full flow near Yungngora community; upstream of Camballin Barrage on 12 March 2009. 


\begin{tabular}{|l|l|c|c|c|c|}
\cline { 3 - 6 } \multicolumn{2}{c}{} & \multicolumn{2}{c|}{ Harvested } & \multicolumn{2}{c|}{ Distributed } \\
\hline \multicolumn{1}{c|}{ Common Name } & \multicolumn{1}{c|}{ Scientific Name } & Daly & Fitzroy & Daly & Fitzroy \\
\hline Barramundi & Lates calcarifer & $*$ & $*$ & $*$ & $*$ \\
\hline Archerfish & Toxotes chatareus & $*$ & $*$ & $*$ & $*$ \\
\hline Mouth Almighty & Glossamia aprion & $*$ & $*$ & $*$ & $*$ \\
\hline Barred Grunter & Amniataba percoides & $*$ & $*$ & $*$ & $*$ \\
\hline Mullet & Liza ordensis & $*$ & $*$ & $*$ & $*$ \\
\hline Tarpon & Megalops cyprinoides & $*$ & $*$ & $*$ & $*$ \\
\hline Catfish & Arius graeffei & $*$ & $*$ & $*$ & $*$ \\
\hline Black Bream & Hephaestus fuliginosus & $*$ & & $*$ & \\
\cline { 2 - 7 } & Hephaestus jenkinsi & $*$ & $*$ & $*$ & $*$ \\
\hline $\begin{array}{l}\text { Spangled Perch } \\
\text { Silver Perch } \\
\text { Silver Bunda } \\
\text { Silver Bream }\end{array}$ & Leiopotherapon unicolor & $*$ & $*$ & $*$ & $*$ \\
\hline $\begin{array}{l}\text { Jewfish } \\
\text { Eel-tailed Catfish } \\
\text { Nailfish } \\
\text { False-spined Catfish }\end{array}$ & Neosilurus pseudospinosus & $*$ & $*$ & $*$ & $*$ \\
\hline
\end{tabular}




\begin{tabular}{|c|c|c|c|c|c|}
\hline $\begin{array}{l}\text { Sleepy Cod } \\
\text { Giant Gudgeon } \\
\text { Flathead Goby }\end{array}$ & Oxyeleotris selheimi & $*$ & $*$ & $*$ & $*$ \\
\hline Long-neck Turtle & Chelodina rugosa & $*$ & * & $*$ & $*$ \\
\hline $\begin{array}{l}\text { Short-neck Turtle } \\
\text { Red-faced Short-neck } \\
\text { Turtle }\end{array}$ & Emydura tanybaraga/victoriae & $*$ & $*$ & $*$ & $*$ \\
\hline Freshwater Crocodile & Crocodylus johnstoni & $*$ & $*$ & $*$ & $*$ \\
\hline $\begin{array}{l}\text { Freshwater Crocodile } \\
\text { Egg }\end{array}$ & Crocodylus johnstoni & $*$ & * & $*$ & $*$ \\
\hline Freshwater Mussel & Velesunio angasi & $*$ & $*$ & $*$ & $*$ \\
\hline Cherabin & Macrobrachium rosenbergii & $*$ & $*$ & $*$ & $*$ \\
\hline Mangrove Jack & Lutjanus argentimaculatus & $*$ & & $*$ & $*$ \\
\hline Yellow-tailed Trumpeter & Amniataba caudavittata & $*$ & & $*$ & $*$ \\
\hline Shark & Carcharhinus leucas & $*$ & & $*$ & $*$ \\
\hline $\begin{array}{l}\text { Wood Duck } \\
\text { Brown Duck }\end{array}$ & Chenonetta jubata & $*$ & & $*^{1}$ & $* 1$ \\
\hline Whistling Duck & Dendrocygna arcuata & $*$ & & $*$ & $*$ \\
\hline Magpie Goose & Anseranus semipalmata & $*$ & & $*$ & $*$ \\
\hline
\end{tabular}




\begin{tabular}{|c|c|c|c|c|c|}
\hline Water Monitor & Veranus mitchelli & $*$ & & & \\
\hline Saltwater Crocodile & Crocodylus porosus & $*$ & & $*$ & $*$ \\
\hline Crocodile Eggs & Crocodylus porosus & $*$ & & $*$ & $*$ \\
\hline Red Claw & Cherax quadricarinatus & $*$ & & $*$ & \\
\hline Pig-nosed Turtle & Carettochelys insculpta & $*$ & & $*$ & \\
\hline Snapping Turtle & Elseya dentata & $*$ & & $*$ & $*$ \\
\hline Lotus Lilies & Nelumbo nucifera & $*$ & & $*^{1}$ & \\
\hline Water Lily & Nymphaea sp. & $*$ & & $*^{1}$ & $*^{1}$ \\
\hline Pandanus leaves & Pandanus aquaticus & $*$ & & $*^{1}$ & $*^{1}$ \\
\hline Bony Bream & Nematalosa erebi & & $*$ & $*$ & $*$ \\
\hline Rainbowfish & Melanotaenia australis & & $*$ & $*$ & $*$ \\
\hline Greenway's Grunter & Hannia greenwayi & & $*$ & & $*$ \\
\hline Longtom & Strongylura krefftii & & $*$ & $*$ & $*$ \\
\hline Freshwater Sawfish & Pristis microdon & & $*$ & $*$ & $*$ \\
\hline Stingray & Himantura dalyensis & & $*$ & $*$ & $*$ \\
\hline Duck & Dendrocygna arcuata & & $*$ & $*$ & $*$ \\
\hline
\end{tabular}




\begin{tabular}{|l|l|c|c|c|c|}
\hline Frog & Litoria spp. & & $*$ & $*$ & $*$ \\
\hline Freshwater Crab & Austrothelphusa transversa & & $*$ & $*$ & $*$ \\
\hline Freshwater Mangrove & Barringtonia acutangula & & $*$ & $*$ & $*$ \\
\hline
\end{tabular}

$3{ }^{1}$ Atlas of Living Australia www.ala.org.au 


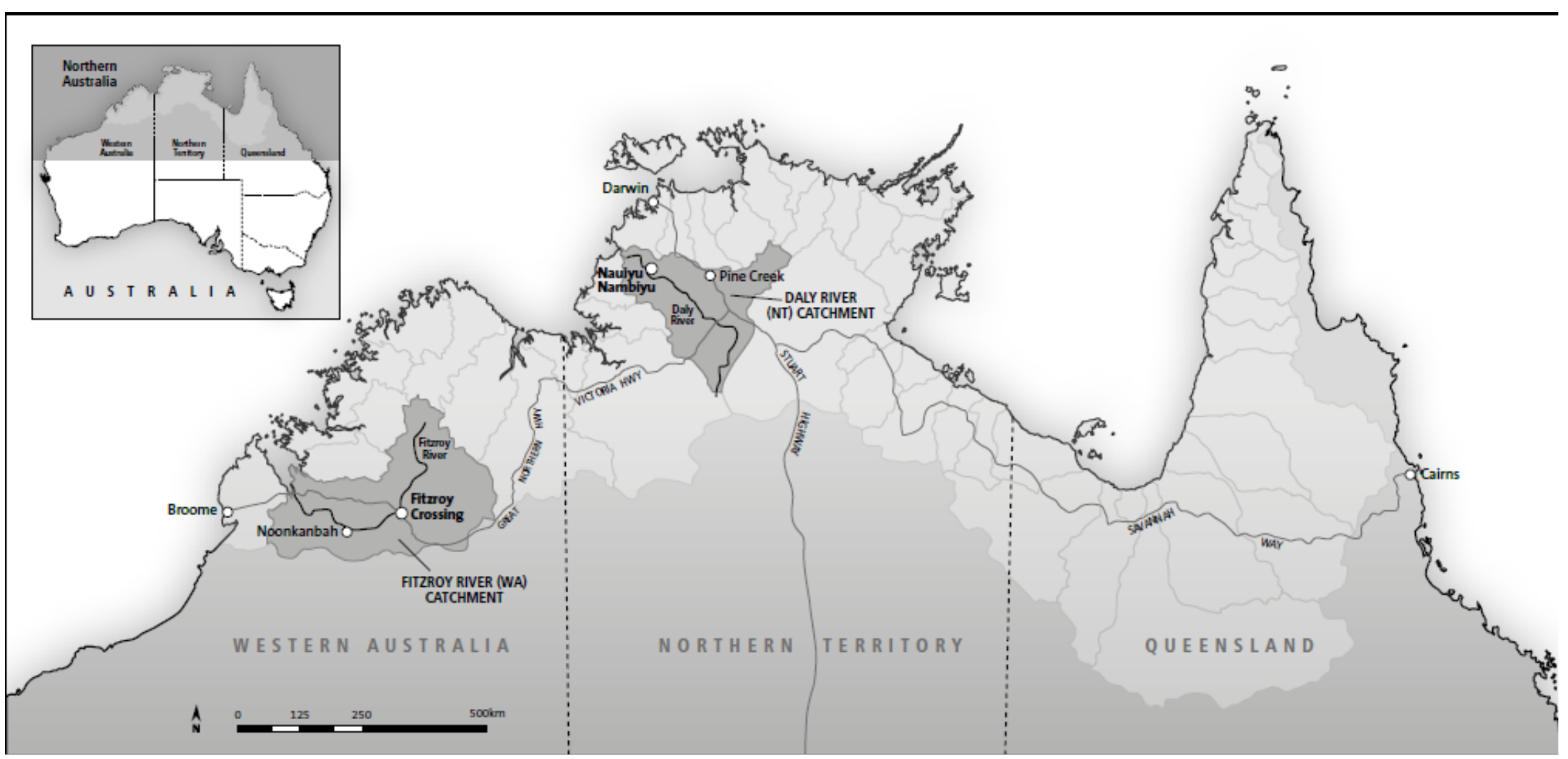




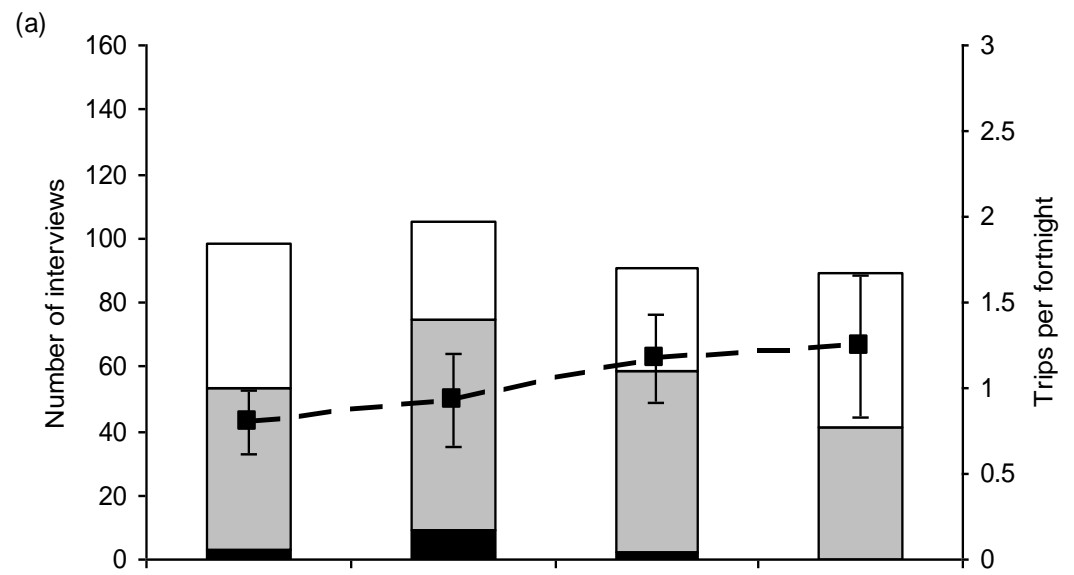

(b)

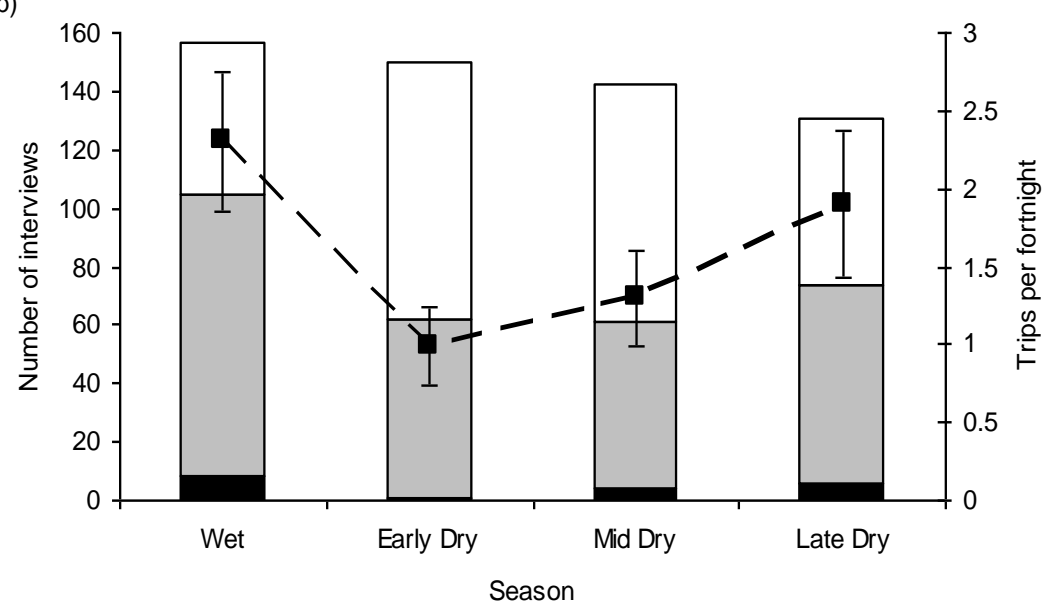

Figure 2: Number of surveys completed in each season (bars) and the mean number of trips per survey (per fortnight) (+/- SE) for survey households in the Daly River (a) and Fitzroy River (b) catchments. Colouration of the bars reflects the number of surveys where respondents declared they went on " 0 " (white), between 1 and 5 (grey) or more than 5 (black) trips in the previous fortnight. 


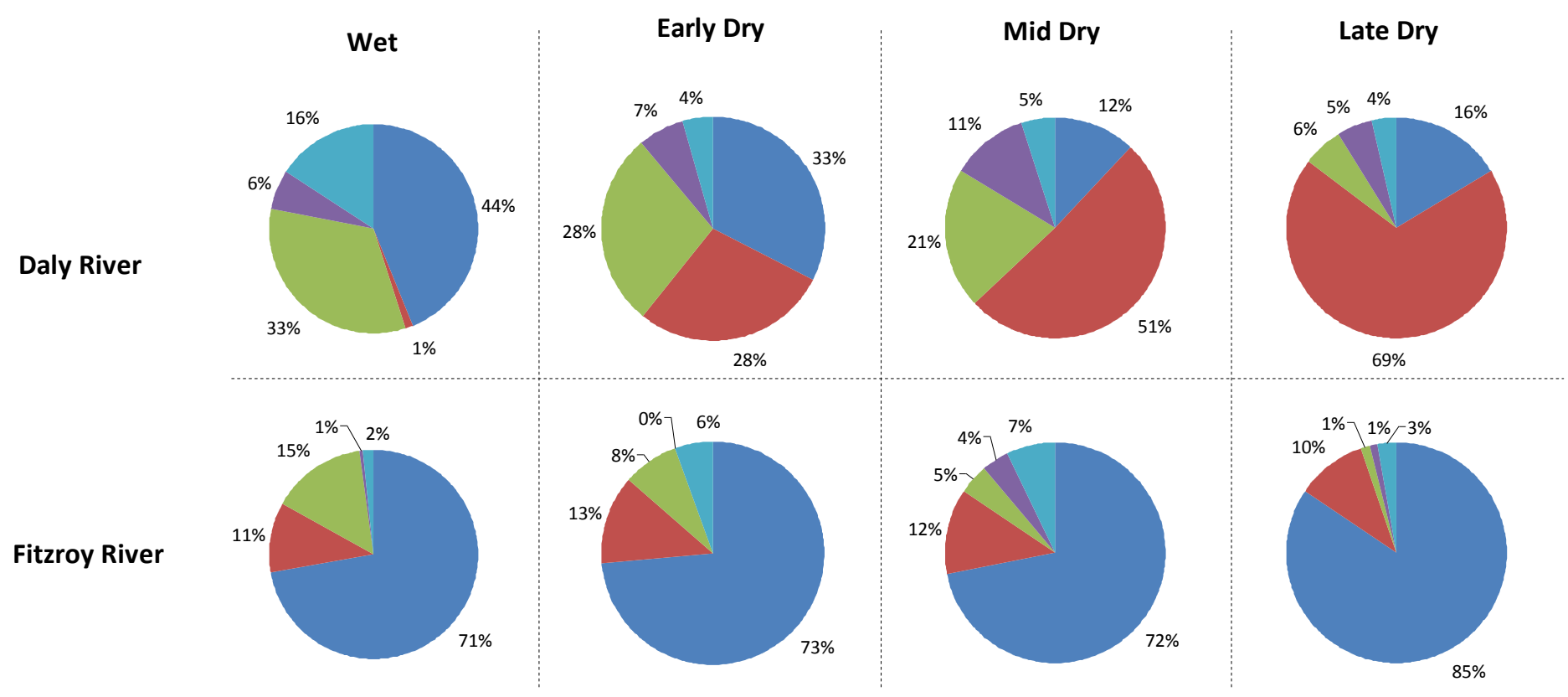

Key
River
Billabong
Creek
- Spring-fed Creek
Other (including "not aquatic")

Figure 3: Percentage of hunting trips visiting habitats in the Daly and Fitzroy River catchments. 

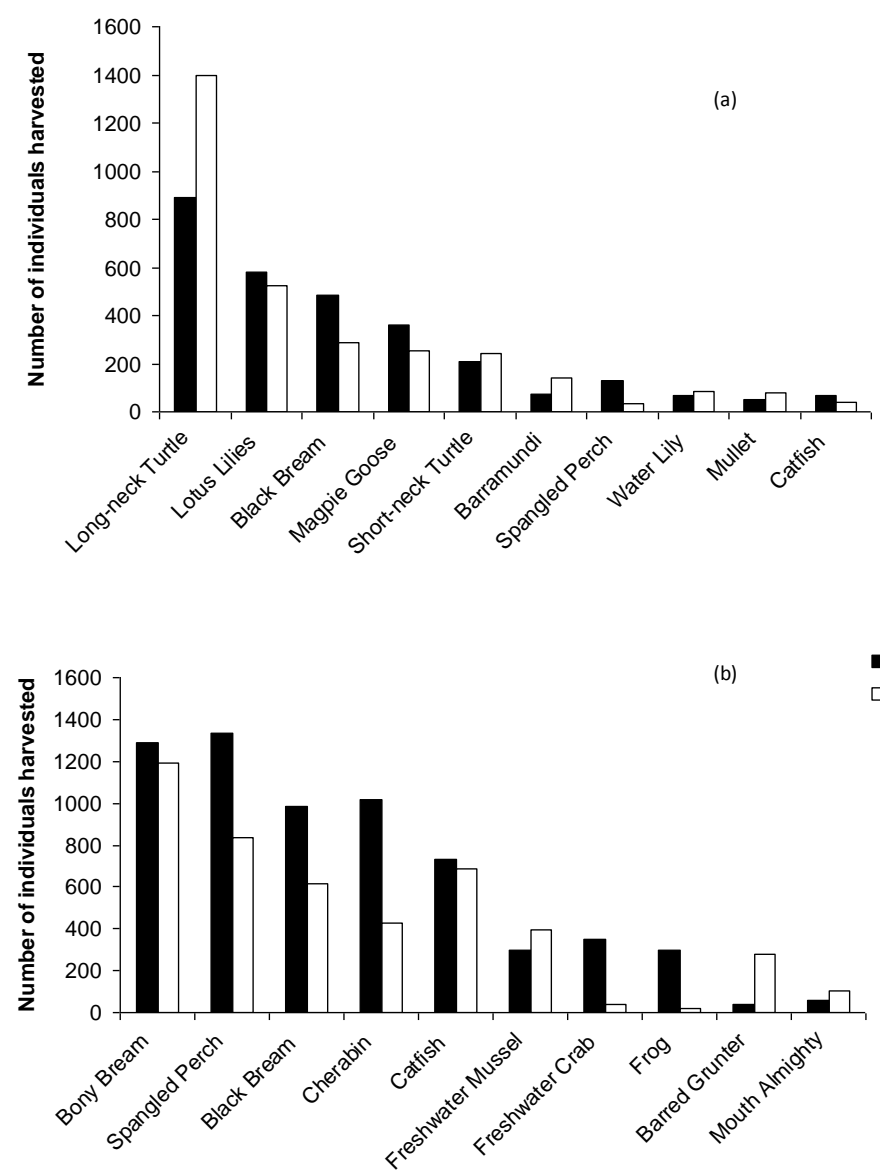

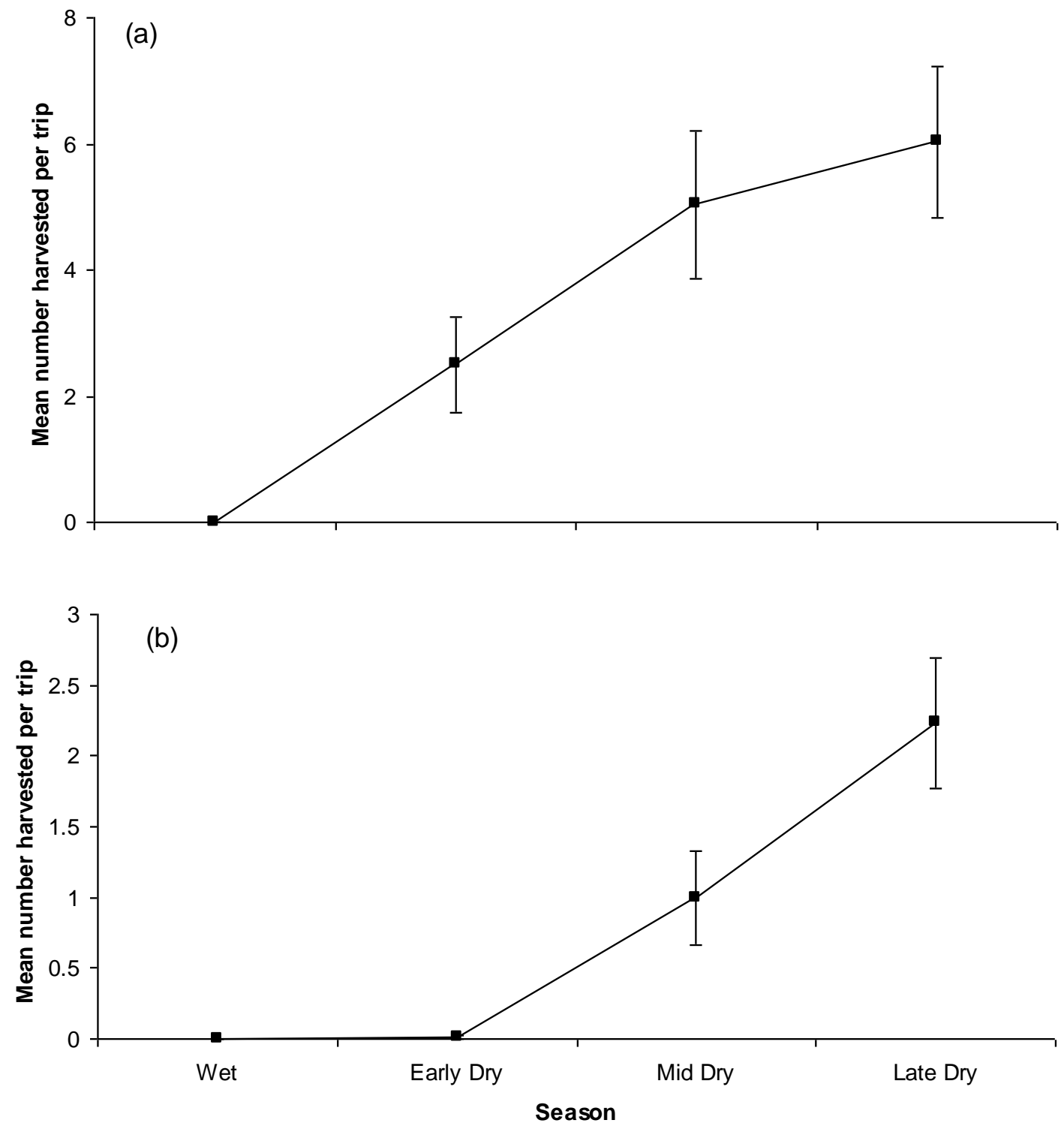
Figure 6: Harvest and consumption of the ten species captured in the highest numbers by survey households in (a) the Daly River and (b) the Fitzroy River catchment. "Harvest" is the total number of individuals of a species harvested by all people involved in the trip, while "consumption" represents the number of species consumed by the survey households or used as bait.
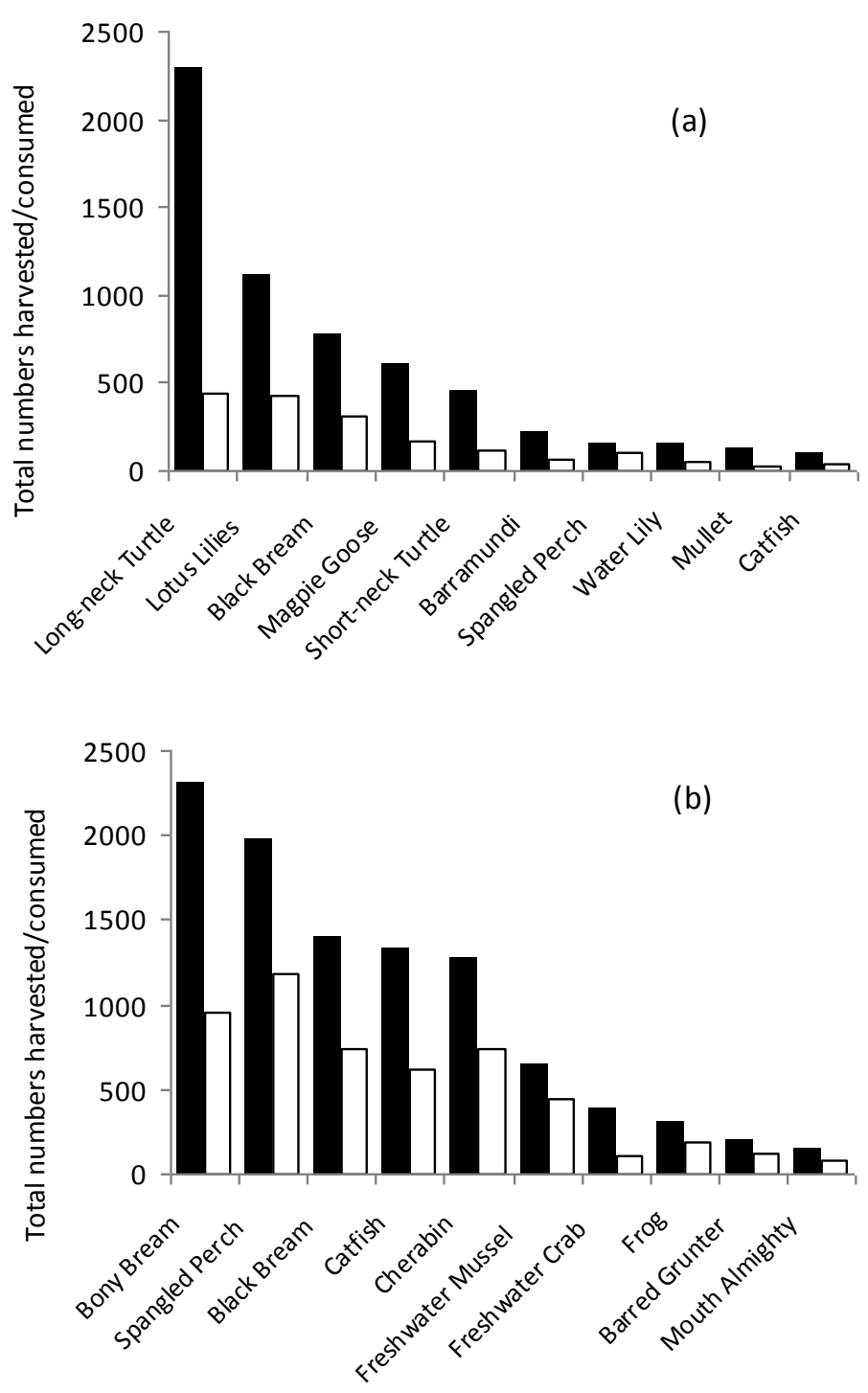

- Harvest

口Consumption 
